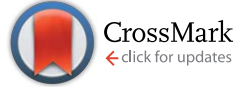

Cite this: RSC Adv., 2017, 7, 15315

Received 11th January 2017 Accepted 3rd March 2017

DOI: $10.1039 / \mathrm{c} 7 \mathrm{ra00454k}$

rsc.li/rsc-advances

\title{
Nanopore sensor for copper ion detection using a polyamine decorated $\beta$-cyclodextrin as the recognition element
}

\begin{abstract}
Yanli Guo, ${ }^{*}$ Feifei Jian and Xiaofeng Kang*
A novel and simple nanopore sensing method has been developed for the detection of $\mathrm{Cu}^{\text {II }}$ ions using polyamine decorated cyclodextrin as the recognition element. The strong binding affinity between $\mathrm{Cu}^{\text {II }}$ and the amino groups of cyclodextrin inside an $\alpha$-hemolysin pore causes the new current blockade events. The event frequency is linear for concentrations of $\mathrm{Cu}^{\prime \prime}$ in the range $0.08-20 \mu \mathrm{M}$. The detection limit is as low as $12 \mathrm{nM}$. More significantly, the sensing system is highly specific for $\mathrm{Cu}^{\prime \prime}$ and does not respond to other metal ions with concentrations up to 10 fold that of $\mathrm{Cu}^{\prime \prime}$. The applicability of this sensor has also been verified by the analysis of $\mathrm{Cu}^{\prime \prime}$ ions in running water, suggesting the potential application of this sensing system.
\end{abstract}

\section{Introduction}

Nanopore stochastic sensing based on single-molecule recognition is an emerging analytical technique on account of having high sensitivity and being rapid and low-cost. ${ }^{1,2}$ The principle of nanopore sensing is to monitor the ionic current modulation caused by analytes driving through nanopores under a fixed applied voltage. ${ }^{3}$ The characteristics of current modulation signatures, including frequency, amplitude and dwell time, depend upon the size, charged status and concentration of the analytes. In this way, nanopore sensing has been used successfully to detect a wide variety of substances, ranging from tiny metal ions ${ }^{4-6}$ to organic molecules ${ }^{7-9}$ and even biological macromolecules such as nucleic acids, ${ }^{10-12}$ protein $^{13-15}$ and peptides. $^{16,17}$ Furthermore, protein nanopores have shown attractive prospects as a next-generation DNA sequencing platform. ${ }^{18}$

So far, sensing metal ions with an $\alpha$-hemolysin ( $\alpha \mathrm{HL})$ nanopore can be realized in two ways. One is to mutate the protein to construct binding sites in the lumen of $\alpha \mathrm{HL}$. Choi and Mach used an $\alpha \mathrm{HL}$ mutant pore with four cysteine mutations to detect $\mathrm{Ag}^{\mathrm{I}}$ and $\mathrm{Cd}^{\mathrm{II}}{ }^{19}$ Braha's group reported simultaneous detection of $\mathrm{Zn}^{\mathrm{II}}$, $\mathrm{Co}^{\mathrm{II}}$ and $\mathrm{Cd}^{\mathrm{II}}$ using an engineered pore containing histidine residues. ${ }^{20}$ Similar research has been conducted by Kasianowicz et al. ${ }^{21}$ Another method is based on the interaction of metal ions and DNA or peptides. $\mathrm{Pb}^{\mathrm{II}}$ was successfully detected by inducing the conformational change of the G4 DNA aptamer. ${ }^{22}$ Wen and colleagues designed specific T-

Key Laboratory of Synthetic and Natural Functional Molecular Chemistry, College of Chemistry \& Materials Science, Northwest University, Xi'an 710127, P. R. China. E-mail: guoyl@nwu.edu.cn; kangxf@nwu.edu.cn; Fax: +86-029-81535026; Tel: +86029-81535026 rich DNA oligomers as probes to detect $\mathrm{Hg}^{\mathrm{II}}$ ions. ${ }^{4}$ Subsequently, they extended this strategy for the detection of $\mathrm{Pb}^{\mathrm{II}}$ and $\mathrm{Ba}^{\mathrm{II}}$ ions. $^{5}$ Furthermore, a polyhistidine peptide chain was exploited to detect $\mathrm{Cu}^{\mathrm{II}}$ based on the chelating reaction by Wang et al. ${ }^{23}$ However, effective sensors with good selectivity, reproducibility and maneuverability are rare. There are still some problems that remain to be solved. First, it is difficult to operate and imitate for the method of modifying the nanopore interior due to the complexity of mutagenesis and separation of protein nanopore. Second, strong background disturbance exists in detecting low concentration metal ions, limiting the sensitivity of the method. Therefore, there is an upsurge of need in the development of a new approach to overcome these limitations.

In the present work, we used the polyamine decorated cyclodextrins as recognition element in $\alpha \mathrm{HL}$ pore for the highly sensitive and selective detection of $\mathrm{Cu}^{\mathrm{II}}$ ion, which is a wellknown heavy metal and plays a vital role in many biological processes. ${ }^{24-26}$ Its concentration will directly affect people's health. ${ }^{27,28}$ As is well known, cyclodextrins could be lodged noncovalently within the lumen of the $\alpha \mathrm{HL}$ pore and produced a substantial and incomplete channel block. ${ }^{29}$ The host-guest inclusion of cyclodextrins with analytes could generate additional transient reductions in the current, which permitted the analytes to be identified and quantified. ${ }^{30}$ Modified $\beta$-cyclodextrins ( $\beta C D s$ ) have been also covalently attached to the pore to differentiate deoxynucleotides with over $99 \%$ confidence. ${ }^{31}$ Moreover, chiral discrimination was achieved by $\alpha \mathrm{HL}$ pore equipped with the $\beta \mathrm{CD}$ adapter. ${ }^{32}$ However, previous studies involving cyclodextrins have been mainly focused on organic molecules, ${ }^{33,34}$ no attention has been paid to the applications for metal ions. Herein, we detect $\mathrm{Cu}^{\mathrm{II}}$ for the first time with $\alpha \mathrm{HL}$ nanopore containing a functionalized cyclodextrin. In this method, mutating the protein to construct binding sites for the 
$\mathrm{Cu}^{\mathrm{II}}$ is not necessary, which simplifies the fabrication of nanopore sensors. More importantly, we validated the practicality of this method for the detection of $\mathrm{Cu}^{\mathrm{II}}$ in environmental samples through analyses of running water.

\section{Experimental section}

\subsection{Reagents and materials}

The $(\mathrm{WT})_{7},(\mathrm{M} 113 \mathrm{~F})_{7}$ and $(\mathrm{M} 113 \mathrm{R})_{7} \alpha \mathrm{HL}$ protein were synthesized and purified according to the methods reported from documents. ${ }^{7,35}$ All the metal salts, $\mathrm{CuCl}_{2}(>99 \%), \mathrm{HgCl}_{2}(>99 \%)$, $\mathrm{CuCl}_{2}$ (>99\%), $\mathrm{ZnCl}_{2}$ (>99\%), $\mathrm{MgCl}_{2}$ (>99\%), $\mathrm{CdCl}_{2}(>99 \%)$, $\mathrm{Co}\left(\mathrm{NO}_{3}\right)_{2}(>99 \%), \mathrm{Ni}\left(\mathrm{NO}_{3}\right)_{2}(>99 \%), \mathrm{Mn}\left(\mathrm{NO}_{3}\right)_{2}(>99 \%), \mathrm{TbCl}_{3}$ $(>99 \%), \mathrm{GdCl}_{3}(>99 \%), \mathrm{Dy}\left(\mathrm{CH}_{3} \mathrm{COO}\right)_{2}(>99 \%)$, purchased from Aladdin and were prepared at concentrations of $10.0 \mathrm{mM}$ each. Heptakis-(6-deoxy-6-amino)- $\beta$-cyclodextrin ( $\left.\mathrm{am}_{7} \beta \mathrm{CD}\right) \quad(>99 \%)$ was obtained from Cycloab (Budapest, Hungary). Both $\mathrm{NaCl}$ $(>99 \%)$ and Tris (>99\%), used to prepare electrolyte solution, were obtained from Kermel Chemical Reagents Co., Ltd. (Tianjin, China). It should be noted that the $\mathrm{pH}$ of the electrolyte solutions adjusted by using hydrochloric acid. All reagents were dissolved in ultrapure water. Teflon film $(25 \mu \mathrm{m})$ was ordered from Goodfellow Corp. (Malvern, PA, USA). The 1,2diphytanoyl-sn-glycero-3-phosphocholine (DPhPC) used for planar bilayer lipid formation was gained from Avanti Polar Lipids (Alabaster, AL, USA). Running water sample was collected from Northwest University (Xian, China). The sample was filtered through a $0.22 \mu \mathrm{m}$ membrane (Shanghai Xin Ya Purification Equipment Co., Ltd., China) prior to the detection.

\subsection{Single channel recording}

Single channel electrical measurements were carried out by using traditional methods. For simplify, planar lipid bilayer membranes of DPhPC were typically created using the method of Montal and Mueller ${ }^{36}$ on an aperture 120-150 $\mu \mathrm{m}$ in diameter in a Teflon film which separates two identical compartments. Each compartment was filled with $1500 \mu \mathrm{L}$ of buffer solution (cis buffer and trans buffer). Both sides of aperture were pretreated with a $10 \% \mathrm{v} / \mathrm{v}$ hexadecane/pentane mixture before the addition of buffer solution. Then the compartments were both injected with $900 \mu \mathrm{L}$ buffer solution to the level just below the aperture and lipid solution was added to buffer. When the pentane was evaporated, solvent-free lipid monolayer formed at the solution-air interface. The remaining $600 \mu \mathrm{L}$ buffer solution was introduced to compartments until the level of buffer rose above the aperture. Unless otherwise stated, $(\mathrm{M} 113 \mathrm{~F})_{7}$ pores were added to the grounded cis compartment (0.05-0.2 ng $\left.\mathrm{mL}^{-1}\right)$. After the successful insertion of a single $\alpha \mathrm{HL}$ pore, copper ions and $a_{7} \beta C D$ were added to the cis and trans side respectively. The single channel current was detected with two freshly prepared $\mathrm{Ag} / \mathrm{AgCl}$ electrodes, collected with a patch clamp amplifier (Axopatch 200B, Axon Instruments, Foster city, CA, USA) and filtered with a low-pass Bessel filter with a corner frequency of $5 \mathrm{kHz}$ and then digitized with a Digidata $1440 \mathrm{~A} \mathrm{~A} / \mathrm{D}$ converter (Axon Instruments) at a sampling frequency of $20 \mathrm{kHz}$.

\subsection{Data analysis}

Single channel current recordings were performed and analyzed with pClamp 10.3 (Axon Instruments). Origin 8.5 (Microcal, Northampton, MA) was employed for histogram construction, curve fitting and graph presentation. Both the values of $\tau_{\text {on }}$ (the mean interevent interval) and $\tau_{\text {off }}$ (the mean dwell time) for $\mathrm{am}_{7} \beta \mathrm{CD}-\mathrm{Cu}^{\mathrm{II}}$ complexes, were obtained from the dwell time histograms by fitting the distributions to single exponential functions by the Levenberg-Marquardt procedure. ${ }^{\mathbf{1 6}}$ The current blockades were produced by the fitted Gaussian distributions.

\section{Results and discussion}

\subsection{The principle of the $\mathrm{Cu}^{\mathrm{II}}$ detection}

Inspired by the successful applications of copper complexes of polyamines decorated cyclodextrin ${ }^{37}$ and the wealth of information about cyclodextrins interacted with $\alpha$ HL nanopore, ${ }^{38}$ we designed that a simple but efficient $\mathrm{Cu}^{\mathrm{II}}$ ions sensor which could be operate easily under mild conditions. As shown in Scheme 1 , we used $\beta$-cyclodextrin with the seven primary hydroxyls replaced with amino groups (heptakis-(6-deoxy-6amino)- $\beta$-cyclodextrin; $\mathrm{am}_{7} \beta \mathrm{CD}$ ) as recognition element, which possess a range of nitrogen donor atoms and are very effective ligands for $\mathrm{Cu}^{\mathrm{II}}$ ions with high specificities. Without $\mathrm{Cu}^{\mathrm{II}}$ ions, $\mathrm{am}_{7} \beta \mathrm{CD}$ adapter which entered into the lumen of the $\alpha$ HL pore only produced one kind of events. In sharp contrast, upon addition of $\mathrm{Cu}^{\mathrm{II}}$ ions to electrolyte solution, they would coordinate with $\mathrm{am}_{7} \beta \mathrm{CD}$ molecules and form $\mathrm{am}_{7} \beta \mathrm{CD}-\mathrm{Cu}^{\mathrm{II}}$ complexes, which resulted in new additional current blockade events having significantly different signatures from those in the absence of $\mathrm{Cu}^{\mathrm{II}}$ ions. It permitted the $\mathrm{Cu}^{\mathrm{II}}$ ions to be readily recognized.

To demonstrate this hypothesis, our initial experiments were carried out at pH 8 under identical conditions with different $\alpha$ HL nanopore containing an $\mathrm{am}_{7} \beta \mathrm{CD}$ adapter as the detector. As displayed in Fig. 1, significant differences in event signature were observed before and after addition of $\mathrm{Cu}^{\mathrm{II}}$ ions for three protein nanopores. It is clear that dwell time of $\mathrm{am}_{7} \beta \mathrm{CD}$ was quite different $(3.97 \pm 0.18 \mathrm{~ms})$ in $(\mathrm{WT})_{7}$ and $(1.03 \pm 0.09 \mathrm{~ms})$ in $(\mathrm{M} 113 \mathrm{R})_{7}$. In the case of $(\mathrm{M} 113 \mathrm{~F})_{7}$ pore, the $\mathrm{am}_{7} \beta \mathrm{CD}$ adapter almost permanently locked into a state of $77.2 \pm 0.5 \%$ block. It has been reported that sensing with molecular adapter would be enhanced if the adapter did not every so often dissociate from the pore..$^{39}$ As a result, the $(\mathrm{M} 113 \mathrm{~F})_{7}$ protein could provide an enhanced resolution for $\mathrm{Cu}^{\mathrm{II}}$ ions recognition compared with that observed in other $\alpha \mathrm{HL}$ pore.

To further prove that the new type of events are related to the formation of $\mathrm{am}_{7} \beta \mathrm{CD}-\mathrm{Cu}^{\mathrm{II}}$ complexes, control experiments were examined. Firstly, when EDTA was introduced to the solution, we found that these events originated from $a_{7} \beta C D$ were eliminated, which demonstrated a strong association between $\mathrm{Cu}^{\mathrm{II}}$ ions and these events (Fig. 2a). Further, $\mathrm{am}_{7} \beta \mathrm{CD}$ in nanopore stochastic sensing was replaced with natural $\beta C D$. The results showed that no additional events was observed in 


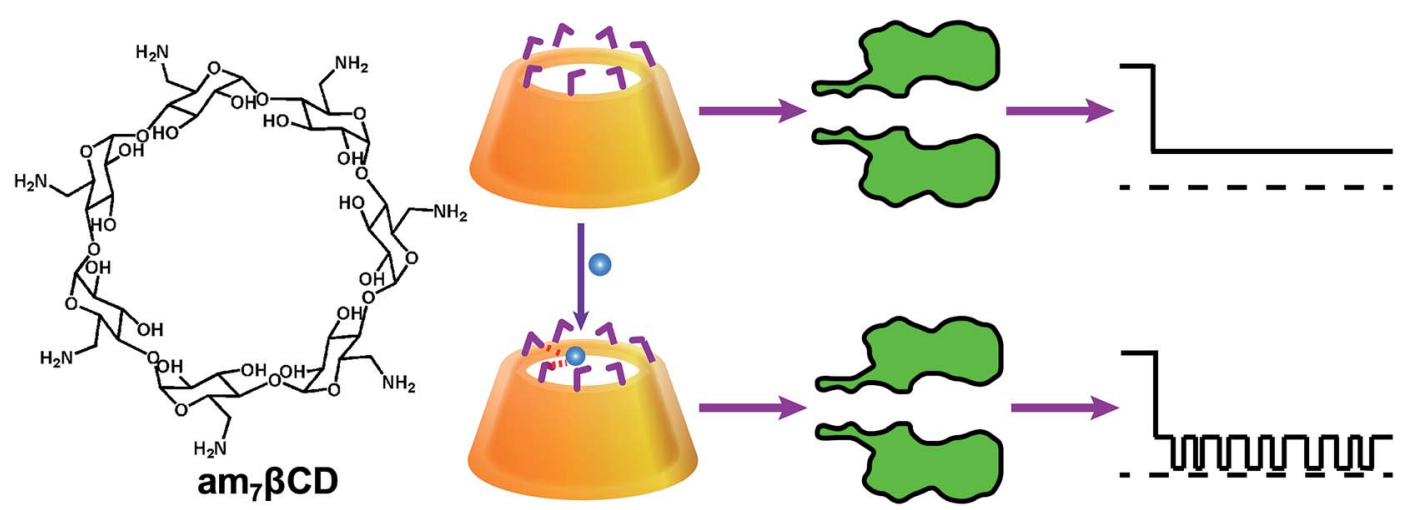

Scheme 1 Cartoon showing $C u^{\prime \prime}$ ions recognition with a protein nanopore using $a_{7} \beta C D$ as recognition element. The am $7 B C D$ and am ${ }_{7} \beta C D-$ $\mathrm{Cu}^{\prime \prime}$ complexes with the pore produced events having significantly different signatures, thus permitting them to be readily distinguished. Chemical structure of $a_{7} \beta C D$ molecule was shown in the left.
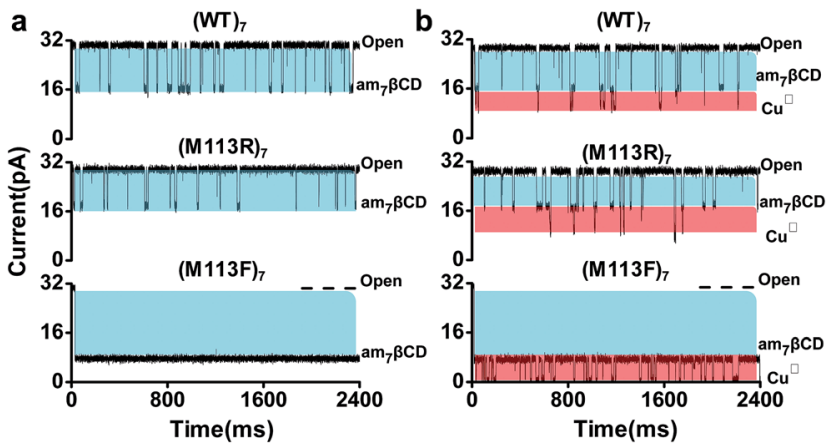

Fig. 1 Typical single-channel current recording traces showing the effect of $\alpha \mathrm{HL}$ protein pore on $\mathrm{Cu}^{\prime \prime}$ ions detection. The experiments were performed at $40 \mathrm{mV}$ in three different $\alpha \mathrm{HL}$ nanopores containing an $\mathrm{am}_{7} \beta C D$ molecule before (a) and after (b) addition of $\mathrm{Cu}^{\prime \prime}$ ions. Conditions: $20 \mu \mathrm{M} \mathrm{Cu}$ il ions added from the cis side and $40 \mu \mathrm{M}$ $\mathrm{am}_{7} \beta C D$ from the trans side, $1 \mathrm{M} \mathrm{NaCl}, 10 \mathrm{mM}$ Tris, $\mathrm{pH} 8$.

the current trace, confirming the role that $\mathrm{am}_{7} \beta \mathrm{CD}-\mathrm{Cu}^{\mathrm{II}}$ complexes play in the $\mathrm{Cu}^{\mathrm{II}}$ ions detection (Fig. 2b).

\subsection{Optimization of detection conditions}

In order to achieve high sensitivity and selectivity of detection of $\mathrm{Cu}^{\mathrm{II}}$ ions, the optimal detection conditions are essential. To begin with, we compared the signals where $\mathrm{Cu}^{\mathrm{II}}$ ions were added from the trans side of the bilayer and the case where $\mathrm{Cu}^{\mathrm{II}}$ ions were added from the cis side of the bilayer (Fig. 3). In general, the transport of the charged analytes through the nanopore was dominated by electrophoresis. Since $\mathrm{Cu}^{\mathrm{II}}$ ions have positive charges, we anticipated the $\mathrm{Cu}^{\mathrm{II}}$ ions to traverse more easily the nanopore from trans to cis side instead of from cis to trans when positive voltage was applied to the trans chamber. However, the experimental results showed that the event frequency of $\mathrm{Cu}^{\mathrm{II}}$ ions from trans side was 10 times than from cis side, in apparent contradiction with the assumption. In fact, there is a combined action of diffusion, electrophoresis, and electroosmosis in the transport of charged molecules through nanopore. A few experimental studies have demonstrated that the electroosmotic flow (EOF) provided an
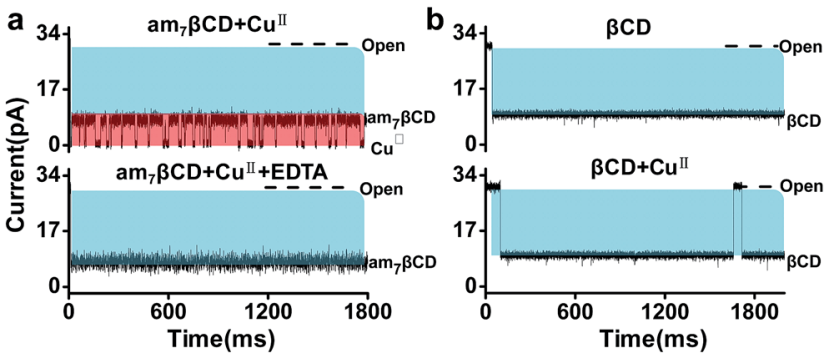

Fig. 2 (a) Typical single-channel current recording traces from a single $(\mathrm{M} 113 \mathrm{~F})_{7}$ pore at $40 \mathrm{mV}$ before (top) and after (bottom) addition of EDTA. (b) Representative single-channel current traces of $\beta C D$ in the absence (top) and presence (bottom) of $\mathrm{Cu}^{\prime \prime}$ ions. Conditions: 40 $\mu \mathrm{M} \mathrm{am}{ }_{7} \beta C D$ or $\beta C D$ added from the trans side, $20 \mu \mathrm{M} \mathrm{Cu}$ II ions and 20 $\mu \mathrm{M}$ EDTA added from the cis side, $1 \mathrm{M} \mathrm{NaCl}, 10 \mathrm{mM}$ Tris, $\mathrm{pH} 8$.

important or even dominant, contribution to the analytes transport, especially for small neutral molecules ${ }^{40,41}$ or molecules with a low net charge, ${ }^{42-44}$ under appropriate experimental conditions. Our experiment phenomenon also was interpreted as EOF being the main force driving electrically. The $\alpha \mathrm{HL}$ protein nanopore exhibits a selectivity to anions ${ }^{45}$ and $\mathrm{am}_{7} \beta \mathrm{CD}$ molecule is positively charged ${ }^{46}$ at $\mathrm{pH}$ 8. Previous studies have demonstrated that anion selective of $\alpha \mathrm{HL}$ becomes more anion selective when natural or the positively charged $\beta C D$ adapter is lodged within the channel lumen. ${ }^{47}$ Therefore, the (M113F) pore equipped with an cationic adapter, $\mathrm{am}_{7} \beta \mathrm{CD}$, was still anion selective. EOF is consist with the direction of anion flow under applied positive voltages. As a consequence, when $\mathrm{Cu}^{\mathrm{II}}$ ions were introduced into the cis chamber, current blockade events occurred preferentially. While following the direction of cation flow and oppositing to EOF, only a few blockades were observed for $\mathrm{Cu}^{\mathrm{II}}$ ions added from the trans side of the bilayer.

As previously documented, the transmembrane voltage is an important factor for determining the translocation of analytes. ${ }^{48,49}$ In addition to providing a novel approach for sensing $\mathrm{Cu}^{\mathrm{II}}$ ions, our sensor permits the determination of association and dissociation rate constants, separately, and formation constants for $\mathrm{am}_{7} \beta \mathrm{CD}-\mathrm{Cu}^{\mathrm{II}}$ complexes. The rate constants of 


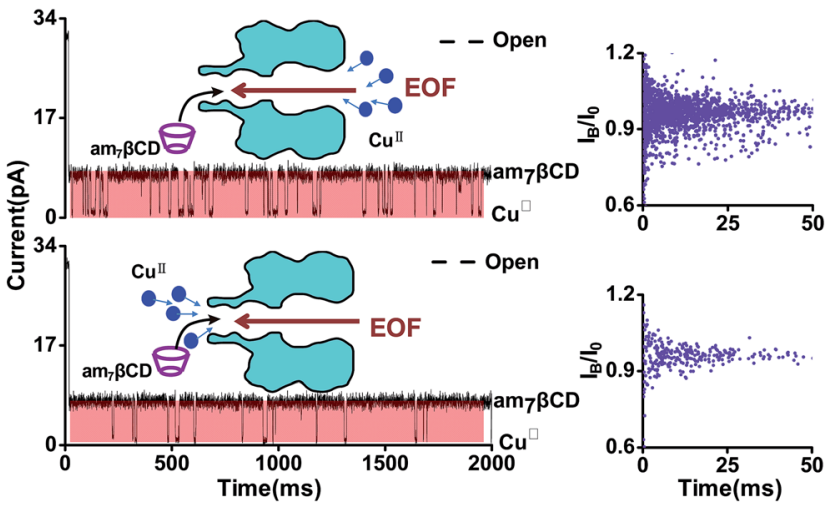

Fig. 3 Representative single-channel current recording traces at $40 \mathrm{mV}$, in presence of $20 \mu \mathrm{M} \mathrm{Cu}$ II ions added from the cis-side (top) or from the trans-side (bottom) of the bilayer. The scatter plots of the events (dwell time vs. current blockage $\left(I_{\mathrm{B}} / I_{0}\right)$ ) for the corresponding current traces showing in the right. Conditions: $40 \mu \mathrm{M} \mathrm{am} \mathrm{m}_{7} \beta C D$ added into the trans chamber, (M113F) $, 1 \mathrm{M} \mathrm{NaCl}, 10 \mathrm{mM}$ Tris, $\mathrm{pH} 8$.

$\mathrm{am}_{7} \beta \mathrm{CD}-\mathrm{Cu}^{\mathrm{II}}$ for association and dissociation were calculated by corresponding formula, that is, $k_{\text {on }}=1 /\left(\tau_{\text {on }}\left[\mathrm{Cu}^{\mathrm{II}}\right]\right)$ and $k_{\text {off }}=$ $1 / \tau_{\text {off }}$. To better illustrate voltage with $\mathrm{Cu}^{\mathrm{II}}$ ions binding events, we did the experiment in which $\mathrm{Cu}^{\mathrm{II}}$ ion was kept constant at 20 $\mu \mathrm{M}$, while transmembrane voltage was changed. As expected, the frequency of event decreased with increasing applied positive voltage, which corresponded to decreases in the association rate constants (Fig. 4a, left). On the contrary, the dissociation rate constant $k_{\text {off }}$ increased with voltage, suggesting that the rather high voltage was harmful for the association of $\mathrm{Cu}^{\mathrm{II}}$ ions (Fig. 4a, middle). Equilibrium formation constants were calculated by using $K_{\mathrm{f}}=k_{\text {on }} / k_{\text {off }}$ for $\mathrm{am}_{7} \beta \mathrm{CD}-\mathrm{Cu}^{\mathrm{II}}$ and differed by over 10-fold under the current experimental conditions (Fig. 4a, right). The most extreme values were produced at the voltage of $40 \mathrm{mV}$ and $160 \mathrm{mV}$. For instance, $\mathrm{Cu}^{\mathrm{II}}$ ions were bound 10.7 times more strongly at $40 \mathrm{mV}\left(K_{\mathrm{f}}=1.5 \pm 0.1 \times 10^{4} \mathrm{M}^{-1}\right)$ than at
$160 \mathrm{mV}\left(K_{\mathrm{f}}=1.4 \pm 0.1 \times 10^{3} \mathrm{M}^{-1}\right)$. These data implied that $\mathrm{Cu}^{\mathrm{II}}$ binding event was favored at lower values of voltage. So as to improve the $\mathrm{Cu}^{\mathrm{II}}$ ions detection sensitivity, we used $+40 \mathrm{mV}$ as the applied voltage in the remaining experiments.

Based on the fact that certain properties of the $\alpha \mathrm{HL}$ protein pore are dependent, to a great extent, on $\mathrm{pH}$, including the ion selectivity, conductance, charge state and magnitude of singlechannel noise. ${ }^{49-51}$ Thus, we carried out the $\mathrm{Cu}^{\mathrm{II}}$ ion detection experiments with $\mathrm{am}_{7} \beta \mathrm{CD}$ at three different $\mathrm{pH}$ values (Fig. $4 \mathrm{~b}$ ). The results showed that, in the absence of $\mathrm{Cu}^{\mathrm{II}}$ ions, only one current blockade level was observed at $\mathrm{pH} 8$ and 10. And there was no additional background noise arised from the $\mathrm{am}_{7} \beta \mathrm{CD}$ state, indicating that $\mathrm{am}_{7} \beta \mathrm{CD}$ was firmly held in the $\beta$ barrel of protein nanopore under these conditions. In contrast, there were a lot of substates during occupied by $\mathrm{am}_{7} \beta \mathrm{CD}$ in $\mathrm{pH} 6$ buffer solution, which might be attributed to the conformational changes of $a_{7} \beta C D$ in the lumen of the $\alpha$ HL pore. ${ }^{38}$ On the other hand, the addition of $20 \mu \mathrm{M} \mathrm{Cu}^{\mathrm{II}}$ ions to the buffer solution of pH 8 produced a large number of markedly new blockade events having a mean residual current of $0.49 \pm 0.12 \mathrm{pA}$ and a mean dwell time of $14.82 \pm 1.13 \mathrm{~ms}$. By contrast, no additional current block was detected when $\mathrm{Cu}^{\mathrm{II}}$ ions was applied to the buffer solution, whatever the buffer solution $\mathrm{pH} 6$ or 10. Apart from the interference from the background noise, the possible reason why the event signatures of $\mathrm{Cu}^{\mathrm{II}}$ ions were not detected at $\mathrm{pH}=6$ was that amino groups of the cyclodextrin were completely protonated.$^{46}$ When the buffer solution $\mathrm{pH}$ increased to $10, \mathrm{Cu}^{\mathrm{II}}$ ions were almost hydrolysis entirely. Therefore, the electrolyte solution of $\mathrm{pH} 8$ was selected for the following experiments.

\subsection{Detection sensitivity and selectivity for $\mathrm{Cu}^{\mathrm{II}}$}

To test the sensitivity of this sensor, $\mathrm{Cu}^{\mathrm{II}}$ ions at various concentrations were examined under the optimum experimental conditions. As illustrated in Fig. 5 and $6 a$, the event frequency increased with increasing concentration of added
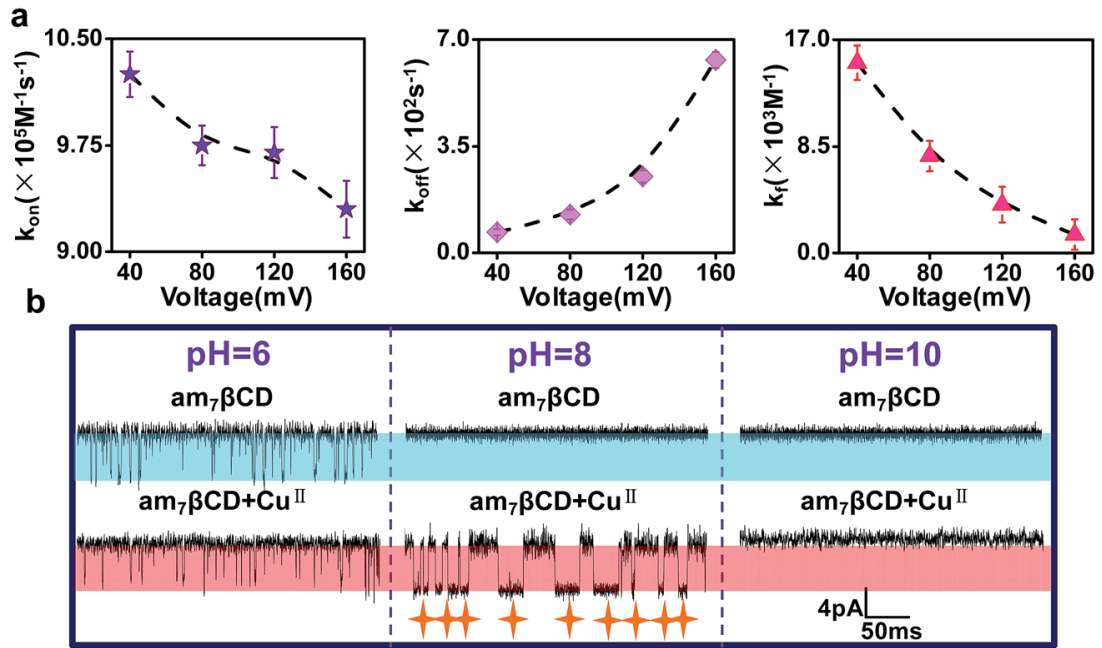

Fig. 4 (a) Dependence of the kinetic constants for the interaction of $\mathrm{Cu}^{\prime \prime}$ with am 7 $\beta C D$ on voltage at pH 8 , (left) $k_{\text {on; }}$ (middle) $k_{\text {off; }}$ ( right) $K_{\mathrm{f}}$. (b) Typical single-channel current recording traces at $40 \mathrm{mV}$, showing the effect of solution $\mathrm{pH}$ on $\mathrm{Cu}^{\prime \prime}$ ions detection. The experiments were performed with $(\mathrm{M} 113 \mathrm{~F})_{7}$ nanopore in a buffer solution comprising $1 \mathrm{M} \mathrm{NaCl}$ and $10 \mathrm{mM}$ Tris. Conditions: $20 \mu \mathrm{M} \mathrm{Cu}$ "ions added from the cis side and $40 \mu \mathrm{M} \mathrm{am}{ }_{7} \beta C D$ from the trans side. 


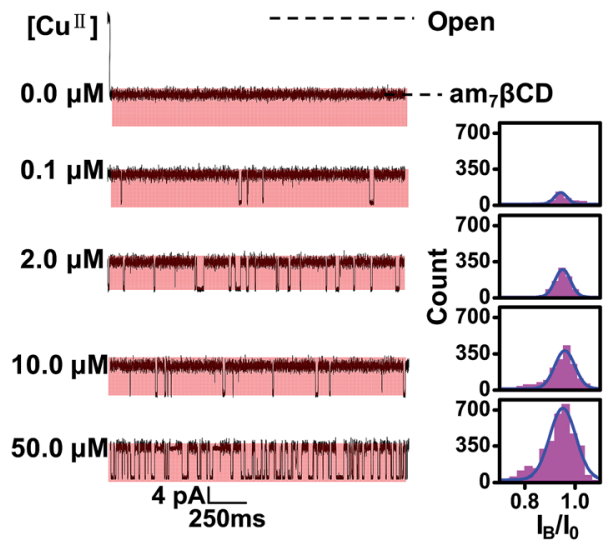

Fig. 5 Nanopore detection of $\mathrm{Cu}^{\prime \prime}$ ions using $\mathrm{am}_{7} \beta C D$ molecule as recognition element. Left panel: representative single channel recordings with the $(\mathrm{M} 113 \mathrm{~F})_{7}$ nanopore of $\mathrm{Cu}^{\prime \prime}$ ions at various concentrations in the presence of $40 \mu \mathrm{M} \mathrm{am}_{7} \beta C D$. Right panel: the corresponding concentration-dependent event amplitude histograms. Conditions: $\mathrm{Cu}^{\prime \prime}$ ions added from the cis side and $\mathrm{am}_{7} \beta C D$ from the trans side, $1 \mathrm{M} \mathrm{NaCl}, 10 \mathrm{mM}$ Tris, $\mathrm{pH} 8,+40 \mathrm{mV}$.
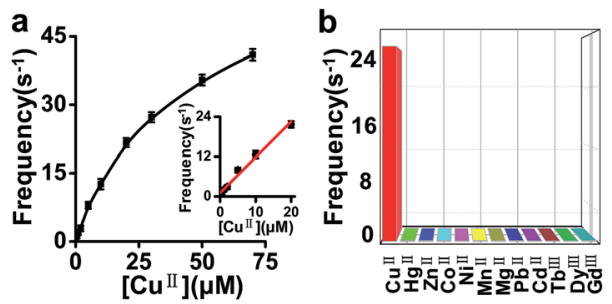

Fig. 6 (a) Dose response curve and (b) selectivity for the $\mathrm{Cu}^{\prime \prime}$ ions nanopore sensor system. The inset of figure (a) shows an enlarged portion of the dose response curve at a range of low $\mathrm{Cu}^{\prime \prime}$ ions concentrations. The experiments were performed at $+40 \mathrm{mV}$ in the presence of $40 \mu \mathrm{M}$ am $7 \beta C D$. Conditions: $200 \mu \mathrm{M}$ interfering ions and various concentration $\mathrm{Cu}^{\prime \prime}$ ions added from the cis side and $40 \mu \mathrm{M}$ $\mathrm{am}_{7} \beta C D$ from the trans side, $(\mathrm{M} 113 \mathrm{~F})_{7}, 1 \mathrm{M} \mathrm{NaCl}, 10 \mathrm{mM}$ Tris, $\mathrm{pH} 8$

$\mathrm{Cu}^{\mathrm{II}}$ ions. Linear regression analysis showed good linearity between the frequency and $\mathrm{Cu}^{\mathrm{II}}$ concentration ranging from $80 \mathrm{nM}$ to $20 \mu \mathrm{M}$ with a correlation coefficient of 0.98 (Fig. 6a, inset). The detection limit of $\mathrm{Cu}^{\mathrm{II}}$ ions could be as low as $12 \mathrm{nM}$ $(\mathrm{S} / \mathrm{N}=3)$, which was lower than previously reported values (LOD $=40 \mathrm{nM}) .{ }^{23}$ Subsequently, under the same conditions, we evaluated the selectivity of this sensing platform toward $\mathrm{Cu}^{\text {II }}(20$ $\mu \mathrm{M})$ relative to other kinds of metal ions including $\mathrm{Pb}^{\mathrm{II}}, \mathrm{Cd}^{\mathrm{II}}$, $\mathrm{Mg}^{\mathrm{II}}, \mathrm{Co}^{\mathrm{II}}, \mathrm{Mn}^{\mathrm{II}}, \mathrm{Ni}^{\mathrm{II}}, \mathrm{Zn}^{\mathrm{II}}, \mathrm{Hg}^{\mathrm{II}}, \mathrm{Dy}{ }^{\mathrm{III}}, \mathrm{Gd}^{\mathrm{III}}$ and $\mathrm{Tb}^{\mathrm{III}}$ (each 200 $\mu \mathrm{M})$. These metal ions, especially $\mathrm{Co}^{\mathrm{II}}, \mathrm{Ni}^{\mathrm{II}}, \mathrm{Zn}^{\mathrm{II}}$ ions, were well known to be able to interact with amino groups. Apparently, the results revealed that no obvious response could be observed upon the addition of other ions (Fig. 6b). Compared with other nanopore sensors for metal ions, our sensor is more selective toward $\mathrm{Cu}^{\mathrm{II}}$ ions over the tested interference ions.

\subsection{Detection of $\mathrm{Cu}^{\mathrm{II}}$ in running water}

To the end, after a number of screenings of experimental conditions, the applicability of this methodology for detecting
Table 1 Results of the detection of $\mathrm{Cu}^{\text {Il }}$ in real sample

\begin{tabular}{llll}
\hline Sample & $\begin{array}{l}\text { Added } \mathrm{Cu}^{\mathrm{II}} \\
(\mu \mathrm{M})\end{array}$ & $\begin{array}{l}\text { Measured } \\
(\mu \mathrm{M})\end{array}$ & $\begin{array}{l}\text { Recovery } \\
(\%)\end{array}$ \\
\hline Running water 1 & 0 & 0.35 & - \\
Running water 2 & 0.50 & 0.82 & 91.4 \\
Running water 3 & 2.00 & 2.37 & 105.7 \\
Running water 4 & 4.00 & 4.38 & 108.6
\end{tabular}

$\mathrm{Cu}^{\mathrm{II}}$ ions in a real sample was further evaluated. The content of $\mathrm{Cu}^{\mathrm{II}}$ ions in the sample of running water were detected and the concentration is $0.36 \pm 0.05 \mu \mathrm{M}$. What's more, as shown in Table 1, the measured values for samples with known amounts of $\mathrm{Cu}^{\mathrm{II}}$ ions showed good recoveries of $91.4-108.6 \%$. The results demonstrated that this nanopore sensor had strong antiinterference ability and could be applied for the detection in real samples.

\section{Conclusions}

In summary, we have developed a simple, selective and sensitive nanopore sensor for detection of $\mathrm{Cu}^{\mathrm{II}}$ ions by employing $\mathrm{am}_{7} \beta \mathrm{CD}$ molecule as recognition element. Based on the chelating reaction between $\mathrm{am}_{7} \beta \mathrm{CD}$ and $\mathrm{Cu}^{\mathrm{II}}$ ions, this sensor has been successfully applied to determination of a wide range of $\mathrm{Cu}^{\mathrm{II}}$ ions from $80 \mathrm{nM}$ to $20 \mu \mathrm{M}$. Compared with other nanopore sensors, our sensing system exhibits relatively low detection limit and better selectivity for $\mathrm{Cu}^{\mathrm{II}}$ ions. More importantly, analyses of running water samples revealed that this approach has potential for detection of $\mathrm{Cu}^{\mathrm{II}}$ ions in real environmental samples.

\section{Acknowledgements}

This work was supported by the National Nature Science Foundation of China (No. 21175105, 21375104 and 21327806), the Specialized Research Fund for the Doctoral Program of Higher Education of China (No. 20126101110015) and the Natural Science Foundation of Shaanxi Province of China (No. 2014JM2050).

\section{References}

1 J. E. Reiner, A. Balijepalli, J. W. Robertson, J. Campbell, J. Suehle and J. J. Kasianowicz, Chem. Rev., 2012, 112, 6431-6451.

2 B. M. Venkatesan and R. Bashir, Nat. Nanotechnol., 2011, 6, 615-624.

3 J. J. Kasianowicz, E. Brandin, D. Branton and D. W. Deamer, Proc. Natl. Acad. Sci., 1996, 93, 13770-13773.

4 S. Wen, T. Zeng, L. Liu, K. Zhao, Y. Zhao, X. Liu and H. C. Wu, J. Am. Chem. Soc., 2011, 133, 18312-18317.

5 C. Yang, L. Liu, T. Zeng, D. Yang, Z. Yao, Y. Zhao and H. C. Wu, Anal. Chem., 2013, 85, 7302-7307. 
6 G. Liu, L. Zhang, D. Dong, Y. Liu and J. Li, Anal. Methods, 2016, 8, 7040-7046.

7 S. Cheley, L. Q. Gu and H. Bayley, Chem. Biol., 2002, 9, 829838.

8 A. J. Boersma, K. L. Brain and H. Bayley, ACS Nano, 2012, 6, 5304-5308.

9 H. C. Wu and H. Bayley, J. Am. Chem. Soc., 2008, 130, 68136819.

10 M. Ayub, S. W. Hardwick, B. F. Luisi and H. Bayley, Nano Lett., 2013, 13, 6144-6150.

11 Y. L. Ying, J. Zhang, R. Gao and Y. T. Long, Angew. Chem., Int. Ed., 2013, 52, 13154-13161.

12 A. Meller, L. Nivon, E. Brandin, J. Golovchenko and D. Branton, Proc. Natl. Acad. Sci., 2000, 97, 1079-1084.

13 J. Nivala, L. Mulroney, G. Li, J. Schreiber and M. Akeson, ACS Nano, 2014, 8, 12365-12375.

14 M. Pastorizagallego, M. F. Breton, F. Discala, L. Auvray, J. M. Betton and J. Pelta, ACS Nano, 2014, 8, 11350-11360.

15 D. Rotem, L. Jayasinghe, M. Salichou and H. Bayley, J. Am. Chem. Soc., 2012, 134, 2781-2787.

16 L. Movileanu, J. P. Schmittschmitt, J. M. Scholtz and H. Bayley, Biophys. J., 2005, 89, 1030-1045.

17 H. Y. Wang, Y. L. Ying, Y. Li, H. B. Kraatz and Y. T. Long, Anal. Chem., 2011, 83, 1746-1752.

18 S. Cornelis, Y. Gansemans, L. Deleye, D. Deforce and N. F. Van, Sci. Rep., 2017, 7, 41759.

19 L. S. Choi, T. Mach and H. Bayley, Biophys. J., 2013, 105, 356364.

20 O. Braha, L. Q. Gu, L. Zhou, X. Lu, S. Cheley and H. Bayley, Nat. Biotechnol., 2000, 18, 1005-1007.

21 J. Kasianowicz, B. Walker, M. Krishnasastry and H. Bayley, MRS Online Proc. Libr., 1993, 330, 217-223.

22 H. Y. Wang, Z. Y. Song, H. S. Zhang and S. P. Chen, Microchim. Acta, 2016, 183, 1003-1010.

23 G. Wang, L. Wang, Y. Han, S. Zhou and X. Guan, Biosens. Bioelectron., 2014, 53, 453-458.

24 A. Badarau and C. Dennison, J. Am. Chem. Soc., 2011, 133, 2983-2988.

25 R. V. Rathod, S. Bera, S. Man and D. Mondal, RSC Adv., 2016, 6, 34608-34615.

26 E. Gaggelli, H. Kozlowski, D. Valensin and G. Valensin, Chem. Rev., 2006, 106, 1995-2044.

27 J. Liu and Y. Lu, J. Am. Chem. Soc., 2007, 129, 9838-9839.

28 S. Lutsenko, A. Gupta, J. L. Burkhead and V. Zuzel, Arch. Biochem. Biophys., 2008, 476, 22-32.

29 L. Q. Gu, O. Braha, S. Conlan, S. Cheley and H. Bayley, Nature, 1999, 398, 686-690.
30 Y. Astier, O. Braha and H. Bayley, J. Am. Chem. Soc., 2006, 128, 1705-1710.

31 J. Clarke, H. C. Wu, L. Jayasinghe, A. Patel, S. Reid and H. Bayley, Nat. Nanotechnol., 2009, 4, 265-270.

32 X. F. Kang, S. Cheley, X. Y. Guan and H. Bayley, J. Am. Chem. Soc., 2006, 128, 10684-10685.

33 L. Q. Gu, S. Cheley and H. Bayley, Science, 2001, 291, 636640.

34 J. Gupta, Q. Zhao, G. Wang, X. Kang and X. Guan, Sens. Actuators, B, 2013, 176, 625-631.

35 L. Wang, Y. Han, S. Zhou, G. Wang and X. Guan, ACS Appl. Mater. Interfaces, 2014, 6, 7334-7339.

36 M. Montal and P. Mueller, Proc. Natl. Acad. Sci., 1972, 69, 3561-3566.

37 G. Impellizzeri, G. Maccarrone, E. Rizzarelli, G. Vecchio, R. Corradini and R. Marchelli, Angew. Chem., Int. Ed., 1991, 30, 1348-1349.

38 L. Q. Gu, S. Cheley and H. Bayley, J. Gen. Physiol., 2001, 118, 481-494.

39 H. C. Wu, Y. Astier, G. Maglia, E. Mikhailova and H. Bayley, J. Am. Chem. Soc., 2007, 129, 16142-16148.

40 F. Piguet, F. Discala, M. F. Breton, J. Pelta, L. Bacri and A. Oukhaled, J. Phys. Chem. Lett., 2014, 5, 4362-4367.

41 S. P. Bhamidimarri, J. D. Prajapati, D. B. B. Van, M. Winterhalter and U. Kleinekathöfer, Biophys. J., 2016, 110, 600-611.

42 L. Mereuta, M. Roy, A. Asandei, J. K. Lee, Y. Park, I. Andricioaei and T. Luchian, Sci. Rep., 2014, 4, 3885.

43 A. Asandei, M. Chinappi, J. K. Lee, S. C. Ho, L. Mereuta, Y. Park and T. Luchian, Sci. Rep., 2015, 5, 10419.

44 A. Asandei, I. Schiopu, M. Chinappi, H. S. Chang, Y. Park and T. Luchian, ACS Appl. Mater. Interfaces, 2016, 8, 1316613179.

45 B. Egwolf, Y. Luo, D. E. Walters and B. Roux, J. Phys. Chem. B, 2010, 114, 2901-2909.

46 B. Hamelin, L. Jullien, F. Guillo, J. M. Lehn, A. Jardy, L. D. Robertis and H. Driguez, J. Phys. Chem., 1995, 99, 17877-17885.

47 L. Q. Gu, S. M. Dalla, J. B. Vincent, G. Vigh, S. Cheley, O. Braha and H. Bayley, Proc. Natl. Acad. Sci., 2000, 97, 3959-3964.

48 O. Braha, J. Webb, L. Q. Gu, K. Kim and H. Bayley, ChemPhysChem, 2005, 6, 889-892.

49 L. Q. Gu and H. Bayley, Biophys. J., 2000, 79, 1967-1975.

50 P. G. Merzlyak, M. F. Capistrano, A. Valeva, J. J. Kasianowicz and O. V. Krasilnikov, Biophys. J., 2005, 89, 3059-3070.

51 O. V. Krasilnikov, M. P. Capistrano, L. N. Yuldasheva and R. A. Nogueira, J. Membr. Biol., 1997, 156, 157-172. 